\title{
An Upper Carboniferous trigonotarbid, Aphantomartus pustulatus (Scudder, 1884), from the Maritimes Basin (Euramerican Coal Province), New Brunswick, Canada
}

\author{
R.F. Miller ${ }^{1}$ and W.H. Forbes ${ }^{2}$ \\ ${ }^{I}$ Steinhammer Palaeontology Laboratory, New Brunswick Museum, Saint John, NB E2K 1E5, Canada \\ $<$ millerrf@nb.aibn.com> \\ ${ }^{2}$ P.O. Box 417, Washburn, ME 04786, U.S.A.
}

Date Received: April 8, 2002

Date Accepted: June 1, 2002

\begin{abstract}
A specimen of an aphantomartid trigonotarbid arachnid, Aphantomartus pustulatus (Scudder, 1884), found in the Upper Carboniferous (Westphalian C, Minto Formation) coalfields of New Brunswick, Canada, is only the second North American locality for this species. Trigonotarbids are uncommon fossils in Carboniferous deposits, most described specimens being found in Europe. Recent revision of the family Aphantomartidae identified only one genus with two species, which range from the Lower Carboniferous (Viséan) to the Lower Permian (Asselian). The specimen is the only aphantomartid trigonotarbid described from the Maritimes Basin of the Euramerican Coal Province.
\end{abstract}

Le spécimen d'arachnide aphantomartide trigonotarbide Aphantomartus pustulatus (Scudder, 1884) découvert dans des terrains houillers du Carbonifère supérieur (Formation du Westphalian C de Minto) du Nouveau-Brunswick, Canada, constitue la deuxième localisation de cet espèce en Amérique du Nord. Les trigonotarbides constituent des fossiles rares dans les gîtes du Carbonifère, la majorité des spécimens décrits ayant été trouvés en Europe. Une révision récente de la famille des Aphantomartidae a défini l'existence d'un seul genre comportant deux espèces, dont la présence s'étend du Carbonifère inférieur (Viséen) au Permien inférieur (Asselien). Le spécimen cité représente le seul trigonotarbide aphantomartide décrit provenant du bassin des Maritimes de la province euraméricaine.

Traduit par la rédaction

\section{INTRODUCTION}

Trigonotarbids are extinct spider-like animals. Although they are known from the Silurian (Prídolí) to the Lower Permian (Asselian) they are best known as occurring in the Upper Carboniferous Coal Measures of Europe, and less commonly in North America (Dunlop 1996; Rössler 1998). Even Carboniferous specimens are rare. "Discovery of an extinct arachnid is always noteworthy" remarked Selden and Romano (1983, p. 106) in their description of the only Upper Carboniferous trigonotarbid arachnid from Spain. The discovery of an extinct trigonotarbid from the Upper Carboniferous of New Brunswick, in eastern Canada, is also a unique occurrence and merits description. A single specimen of an aphantomartid trigonotarbid, identified as Aphantomartus pustulatus (Scudder, 1884), is described from the Minto Formation (Westphalian $\mathrm{C}$ ) in the coalfields of central New Brunswick. It is the only known occurrence of a trigonotarbid from New Brunswick (Copeland 1957). A recent compilation by Calder (1998) listed one anthracomartid trigonotarbid, Coryphomartus triangularis Petrunkevitch, 1913, from the Upper Carboniferous of Joggins, Nova Scotia and Copeland (1957) identified Anthracomartus sp. (possibly Coryphomartus triangularis) from the Canso? Group (Namurian) of Nova Scotia. The present specimen is, therefore, the only known aphantomartid trigonotarbid described from the Maritimes Coal Basin of the "Euramerican Coal Province" (Calder and Gibling 1994), a region that includes extensive areas of present-day Europe and North America underlain, principally, by Late Carboniferous coalbearing formations (Fig. 1). Given that Upper Carboniferous fossils from New Brunswick and Nova Scotia have been studied since the middle of the nineteenth century (Dawson 1868) it is surprising that few trigonotarbids have been described. In New Brunswick, the only Upper Carboniferous arthropod assemblage described in any detail is from the 'Fern Ledges' site in Saint John, first described in 1865 (Hartt 1865). The 'Fern Ledges' assemblage does contain supposed arachnids (Matthew 1889, 1895a, 1895b, 1897). However, the 'Fern Ledges' specimens are poorly preserved and doubt has been cast on the validity of all identifications.

\section{STRATIGRAPHY AND AGE}

The fossil described here was recovered from a plantbearing grey mudstone, most likely from the roof shales overlying the Minto coal seam, in the upper member of the Minto Formation. The specimen was collected on the floor of a strip mine (Hacquebard and Barss 1970) near Minto, New Brunswick (approx. $46^{\circ} 05^{\prime} \mathrm{N} ; 66^{\circ} 04^{\prime} \mathrm{W}$ ). Unfortunately the exact collecting locality is unknown. It was found in the 1970 s 


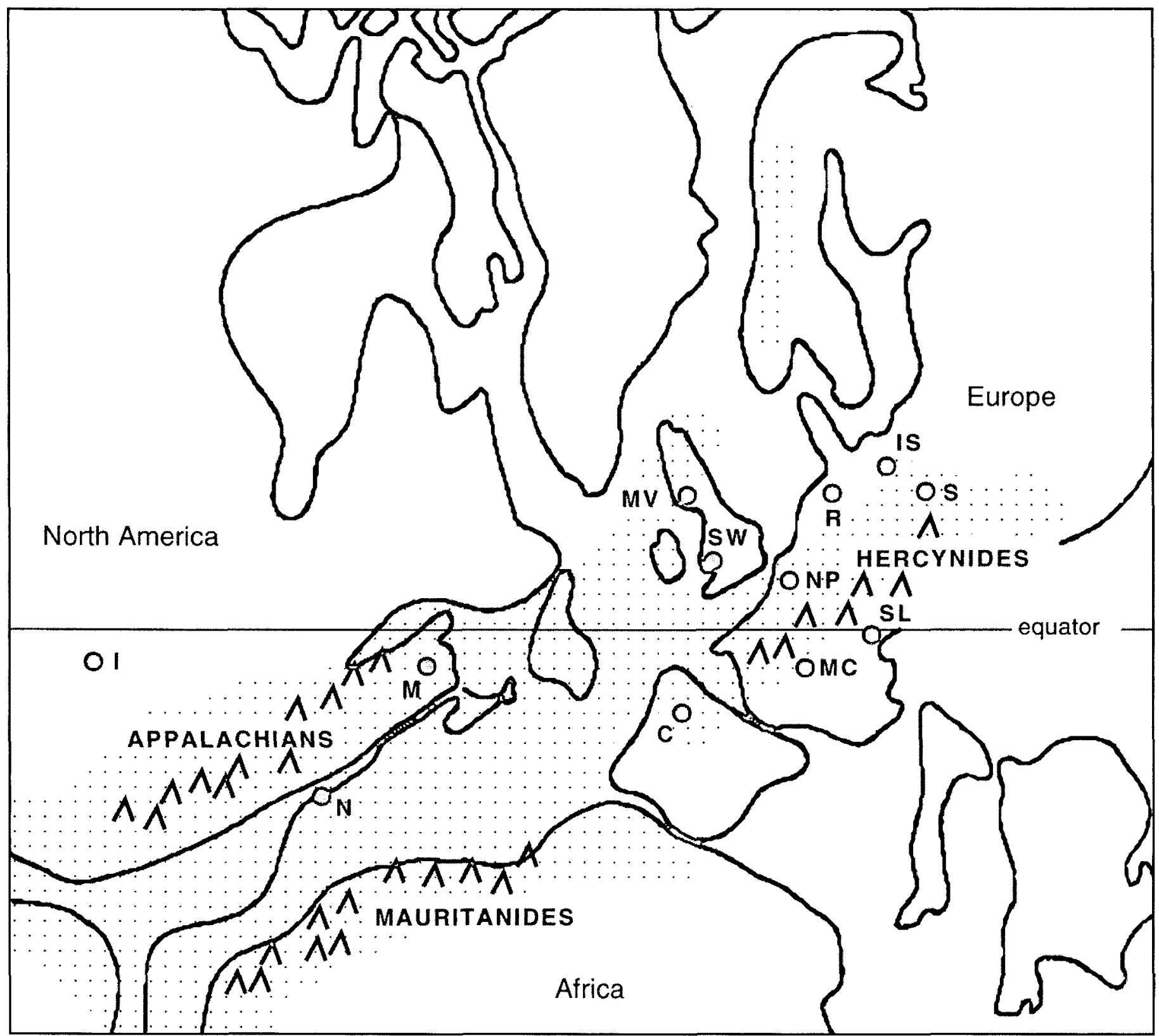

Fig. 1. Late Carboniferous palaeogeography at about $306 \mathrm{Ma}$ showing the positions of major Coal basins in the Euramerican Coal Province (shaded) that contain Aphantomartus. $\mathrm{I}=$ Illinois Basin, $\mathrm{M}=$ Maritimes Basin, $\mathrm{N}=$ Narragansett Basin, $\mathrm{C}=\mathrm{Cantabrian} \mathrm{Mountains}$ Basin, $\mathrm{MC}=$ Massif Central Basin, NP = Nord - Pas de Calais Basin, R =Ruhr Basin, IS = Intersudetic Basin, $\mathrm{S}=$ Silesian Basin, SW = South Wales Basin, MV = Midland Valley Basin, SL = Saar-Lorraine Basin (after Calder and Gibling 1994).

by one of the authors (W.H.F.). Extraction pits in the Minto coalfield are continually opened and backfilled, so identification of the site is now impossible.

The Minto Formation is described as including fossiliferous sandstone, conglomerate, siltstone, shale and coal (St. Peter 1997). The Minto Formation is subdivided into two informal members (Muller 1951; Hacquebard and Barss 1970; Williams et al. 1985). The lower member consists of a grey, buff-weathered, commonly cross-bedded, quartzose sandstone, a pebbly sandstone, and a conglomerate. The upper member includes a greyish-green to buff coloured sandstone, a light grey mudstone and the 'Minto coal seam'. Muller (1951) and Bell (1962) assigned the Minto Formation to the Pictou Group; however, recent mapping (St. Peter 1997) placed the Minto Formation within the Cumberland Group (Williams et al. 1985). Miospores indicate an early Westphalian $C$ (Bolsovian) age for the Minto coal seam (Hacquebard 1972; Kalkreuth et al. 2000) assigned to the Vestispora Zone of Atlantic Canada, equivalent to the basal Torispora securisTorispora laevigata Zone of western Europe, and the lower Torispora securis-Vestispora fenestrata Zone of Illinois. The base of the Westphalian $C$ is currently set at $311 \pm 3 \mathrm{Ma}$ (Okulitch 1999). Flora of the Minto Formation was described by Bell (1962), and recent discoveries of vertebrates (Miller 1999) have enlarged the described fauna of the Minto Formation to include previously unrecorded sharks, acanthodians, lungfish and rhizodonts. 

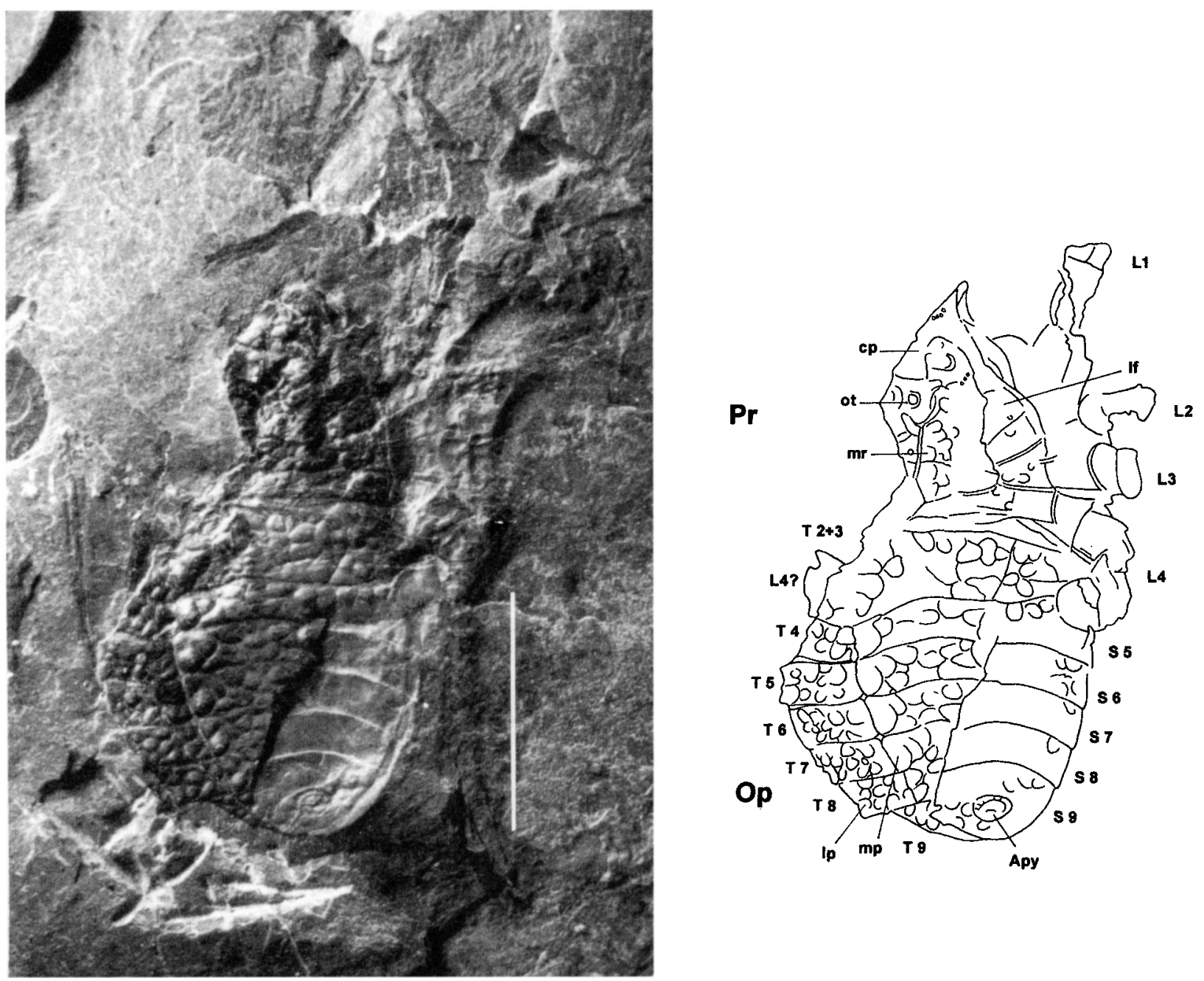

Fig. 2. Photograph and camera lucida drawing of NBMG 4594a, Aphantomartus pustulatus (Scudder, 1884), from the Upper Carboniferous (Westphalian C) Minto Formation near Minto, New Brunswick. Internal mould of the dorsal surface of the prosoma and opisthosoma with partial exposure of the interior ventral surface of the posterior opisthosoma. Abbreviations: Apy $=$ anal pygidium, $\mathrm{cp}=\mathrm{carapace}, \mathrm{L} 1-4=$ walking legs 1 to $4, \mathrm{lf}=$ lateral field, $\mathrm{lp}=$ lateral plate, $\mathrm{mp}=$ median plate, $\mathrm{mr}=$ median ridge, $\mathrm{Op}=$ opisthosoma, ot $=$ ocular tubercle, $\mathrm{Pr}=\mathrm{prosoma}, \mathrm{S} 5-$ S9 $=$ sternites 5 to $9, \mathrm{~T} 2-\mathrm{T} 9=$ tergites 2 to 9 . Scale $=5 \mathrm{~mm}$.

\section{SYSTEMATIC PALAEONTOLOGY \\ Order Trigonotarbida Petrunkevitch, 1949 \\ Family Aphantomartidae Petrunkevitch, 1945 Genus Aphantomartus Pocock, 1911}

Type species: Aphantomartus areolatus Pocock, 1911, from the Mynyddislwyn vein, Maes-y-cwmmer, South Wales, U.K., Upper Carboniferous (Westphalian D).

Diagnosis: In Rössler (1998)

Discussion: Recent revision of the genus Aphantomartus by Rössler (1998) identified two species, A. pustulatus and $A$. areolatus, distinguished largely by their dorsal opisthosomal tuberculation which is larger in $A$. areolatus and smaller and more dense in A. pustulatus.

Aphantomartus pustulatus (Scudder, 1884)

Figs. 2, 3
Original diagnosis: In Scudder (1884, p. 18)

Emended diagnosis: In Rössler (1998, p. 73)

Included species: See Rössler (1998) for synonymies.

Material examined: One specimen (NBMG 4594a, b) preserved as a part and counterpart in grey siltstone with carbonized plant fragments. Specimen NBMG 4594a exhibits the internal mould of the dorsal surface of the prosoma and opisthosoma with partial exposure of the interior ventral surface of the posterior opisthosoma. Specimen NBMG 4594b exhibits the external mould of the dorsal surface of the prosoma and opisthosoma. Deposited at the New Brunswick Museum, Saint John, New Brunswick, Canada.

Occurrence: Minto Formation, Cumberland Group, Westphalian C, from open pit coal mine near Minto, New Brunswick. 

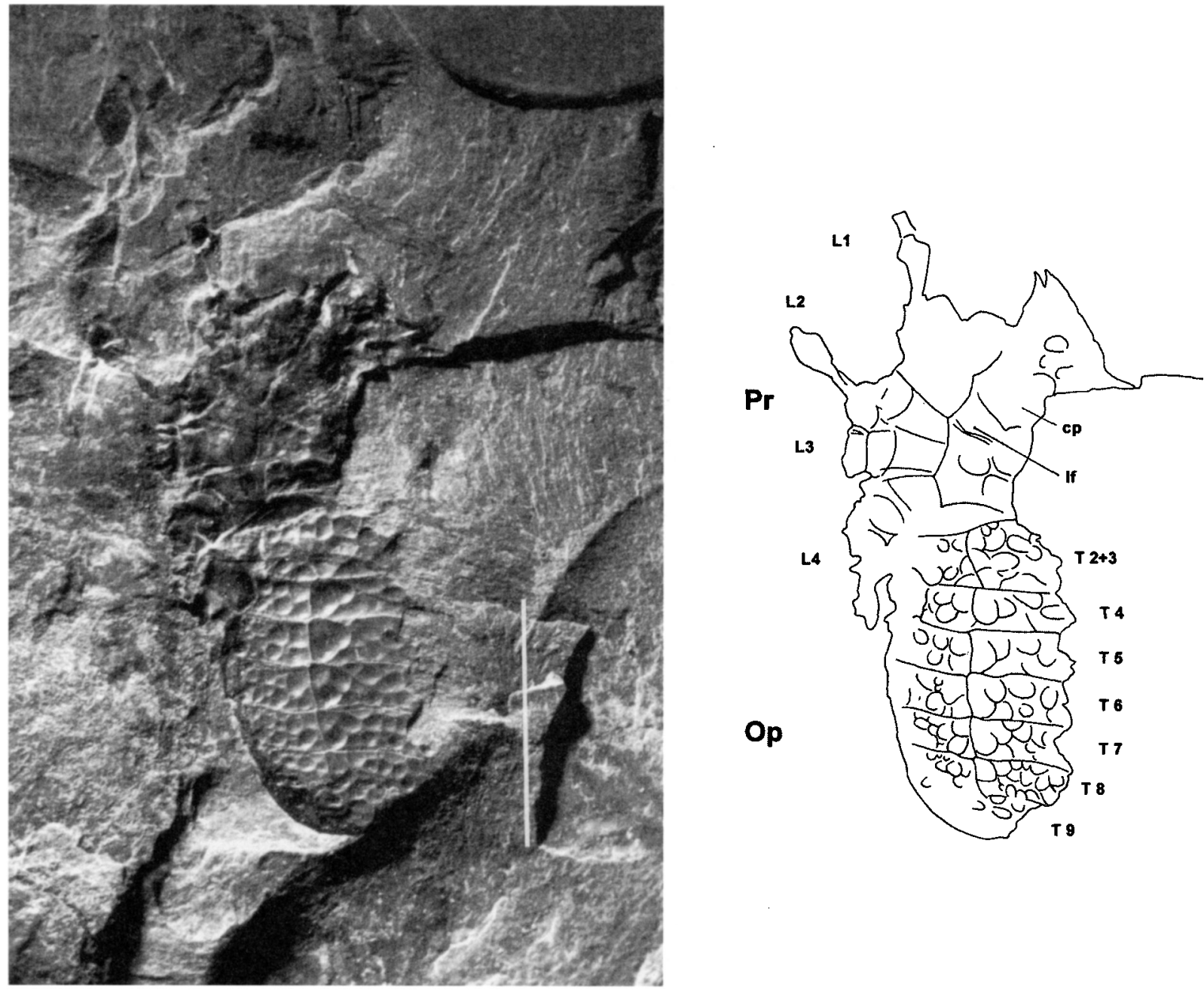

Fig. 3. Photograph and camera lucida drawing of NBMG 4594b, Aphantomartus pustulatus (Scudder, 1884), from the Upper Carboniferous (Westphalian C) Minto Formation near Minto, New Brunswick. External mould of the dorsal surface of prosoma and opisthosoma. Abbreviations: $\mathrm{cp}=$ carapace, $\mathrm{L} 1-4=$ walking legs 1 to 4 , lf $=$ lateral field, Op = opisthosoma, $\operatorname{Pr}=$ prosoma, T2-T9= tergites 2 to 9 . Scale $=5$ $\mathrm{mm}$.

Description: Specimen NBMG 4594 represents a partially preserved, dorsoventrally compressed trigonotarbid. Parts of the left side of the prosoma, and part of the right dorsal opisthosoma are missing. Total length of specimen is approximately $12 \mathrm{~mm}$. Measurements are minimum values. On NBMG 4594a, the dorsal side of the animal is seen impressed upon the ventral side (Fig. 2). The carapace is rotated counterclockwise, revealing part of the ventral side of the prosoma. Opisthosomal sternites are preserved on NBMG $4594 \mathrm{a}$ with the overlying tergites preserved on the counterpart. Specimen NBMG 4594b exhibits the external mould of part of the dorsal surface of prosoma and opisthosoma (Fig. 3).

The prosoma is distorted, obscuring details. The carapace is sub-triangular in shape and slightly wider than long. Carapace length is $5 \mathrm{~mm}$. The anterior apex appears to terminate in two acute cusps, although a rounded margin joins the cusps. Carapace width across posterior margin is approximately $6 \mathrm{~mm}$. The carapace is divided into 4 regions. Posteriorly, a transverse rib likely runs the full width of the carapace. It is approximately $0.6 \mathrm{~mm}$ long, about one-tenth its width. The rest of the carapace is divided into three longitudinal sections. A raised median ridge is flanked by a lateral field with a border scalloped into three shallow embayments. The side of the median ridge is steep where it meets the lateral field. The lateral field is well preserved on the right side of the carapace. The left lateral field is largely missing.

The median ridge, as preserved, has no clear divisions and a maximum width of approximately $3 \mathrm{~mm}$. The anterior apex of the median ridge terminates in a $\mathrm{v}$-shaped point opening toward the anterior of the prosoma. The ocular tubercle rests in the middle of the " $\mathrm{v}$ ". The median ridge is divided into two lobes bisected by a median furrow. Only a portion of the left lobe is visible. The lobe is covered by low irregular-shaped tubercles. It is difficult to define detail in the middle area of the median ridge; however, no transverse furrow posterior to the ocular tubercle can be seen. Two large circular tubercles, about $0.75 \mathrm{~mm}$ in diameter, are found on the ocular tubercle.

The lateral field is separated from the median ridge by a furrow. It is covered in low irregular-shaped tubercles and divided by two furrows which run forward and outward from the median ridge to the scalloped lateral margin. The posterior 
furrow starts near the base of the median ridge and the anterior furrow starts at about the midpoint of the median ridge.

The opisthosoma is elliptical in shape with a length of 7 $\mathrm{mm}$. The width of the opisthosoma at midlength is approximately $8 \mathrm{~mm}$. The dorsal surface of the opisthosoma is covered by tergites (T2+3 to T9) consisting of a median plate, and a lateral plate. The plates are separated by furrows. The tergites are ornamented by large, low elevation, posteriorly directed tubercles separated by shallow furrows. The second tergite is longer than the other tergites. Tergites 2 to 8 have a row of large, flat, multi-lobed, subtriangular tubercles running down the adaxial side of the longitudnal furrow. Tergite 9 is only partially visible. Between the large, flat, subtriangular tubercles on the median portion of the tergite there are additional less prominent tubercles. The lateral plates of each tergite are also covered in tubercles.

Sternite plates (S5 to S9) are visible on the posterior right portion of the opisthosoma (Fig. 2). There are 5 smooth plates divided by furrows. The tubercles visible on the sternites are remnants of the missing plates of the overlying tergites. The anal pygidium is located in the centre of the last sternite.

Part and counterpart of four pedal appendages (L1 to L4) of the right side are visible on NBMG 4594a, b. The pedal appendages consist of a portion of the trochanter(?) of each right leg and possibly the femur and patella on L1. A small part of the left leg (L4?) is also visible on NBMG 4594a.

Both the part and counterpart of the specimen display a fine layer of black, shiny, carbonized cuticle, easily seen under 70 percent ethanol. Dunlop (1999) described previously unseen cuticle ornament of small, rounded tubercles approximately $50 \mu \mathrm{m}$ in diameter on the opisthosoma of $A$. areolatus. NBMG 4594 shows similar-sized tubercles on a small patch of cuticle near the anterior apex of the carapace.

\section{DisCUSSION}

The specimen described here appears consistent in most respects with Aphantomartus pustulatus most recently described by Rössler (1998). Rössler's (1998) revision of the Aphantomartidae recognized one genus with two species $A$. areolatus and $A$. pustulatus. The two species are similar, distinguished largely by their dorsal opisthosomal tuberculation. Rössler's (1998) emended diagnosis indicates A. pustulatus possesses finer tuberculation on the tergites and multiple larger tubercles at the lateral edges of the median tergites than $A$. areolatus and weak tubercles on the lateral lobes of the carapace. $A$. areolatus has a transvere furrow behind the ocular tubercule not present on NBMG 4594. The specimen is referred to $A$. pustulatus based on the density of opisthosomal tubercles, presence of multiple tubercles at the lateral edges of the median tergite plate, absence of a transverse furrow behind the ocular tubercle on the prosoma, and the presence of tubercles on the lateral lobes of the carapace.

\section{CONCLUSIONS}

The specimen described here is identified as Aphantomartus pustulatus, a species erected by Scudder (1884) for a fossil from Mazon Creek, Illinois. Aphantomartus pustulatus and $A$. areolatus have been described from various Coal basins (Rössler 1998) within the Euramerican Coal Province (Fig. 1). Selden and Romano (1983), in their description of $A$. areolatus from the basal Stephanian of Spain, provided a critical discussion of the taxonomic difficulties that have arisen between Trigonomartus Petrunkevitch, 1913 and Aphantomartus Pocock, 1911. They concluded the two were synonymous, with Aphantomartus having priority. Rössler (1998) provided the most recent revision of the Aphantomartidae, including synonymies for both species and an age range for the genus from the Lower Carboniferous (Viséan, older than $327 \mathrm{Ma}$ ) in the Erzgebirge Basin, Germany to the Lower Permian (Asselian, about 296-298 Ma) in the Saale Basin, Germany . (Rössler 1998; Rössler and Brauckmann 2000). In Europe Aphantomartus specimens have been described from the basal Stephanian of Spain in the southwest, to the Namurian of the Czech Republic in the east, north to the Scottish Midland Valley in the United Kingdom and southeast to the Austrian Alps (Rössler 1998; Rössler and Brauckmann 2000). The two previous occurrences in North America include Aphantomartus pustulatus from Mazon Creek, Illinois (Scudder 1884; Beall and Selden 1997) and Trigonomartus woodruffi Scudder, 1893 (Petrunkevitch 1913), likely Aphantomartus (Rössler 1998), from Rhode Island.

Aphantomartus pustulatus from the Westphalian $\mathrm{C}$ of New Brunswick places this specimen at about the middle of the known age range of Aphantomartus. Palaeogeographic reconstruction (Fig. 1) during deposition of the Minto Formation would place New Brunswick and the Maritimes Basin near the middle of the Euramerican Coal Province (Calder and Gibling 1994) along a trough just south of the equator between the Appalachian Mountains to the northwest and the Mauritanides-Hercynides Mountains to the southeast. The basin designations (Calder and Gibling 1994) indicate major coal-bearing regions. The specimen described here from the Maritimes Coal Basin fills a gap between the Illinois Coal Basin near the western end of the Euramerican Coal Province, the Narragansett Coal Basin in Rhode Island to the south, and the European Coal basins of South Wales, the Midland Valley of Scotland, Cantabrian Mountains, Nord-Pas de Calais, Massif Central, Saar-Lorraine, Ruhr, Intrasudetic and Silesian to the east (Rössler 1998).

\section{ACKNOWLEDGEMENTS}

Thanks to J. Dunlop, R. Rössler and P. Selden for their thoughtful reviews of the manuscript and, along with $\mathrm{C}$. Brauckmann, for generously providing reprints regarding trigonotarbids. J. Bishop and C. Little from the NBM Archives and Research Library provided great help finding older papers critical in this study. C. St. Peter and J. Utting helped in gathering information on the Minto Formation.

\section{REFERENCES}

Beall, B.S. \& Selden, P.A. 1997. Arachnida. In C.W. Shabica and A.A. Hay (eds.), Richardson's Guide to The Fossil Fauna of Mazon Creek. Northeastern Illinois University, Chicago, pp. $140-154$. 
Bell, W.A. 1962. Flora of the Pennsylvanian Pictou Group of New Brunswick. Geological Survey of Canada, Bulletin, 87, 71 p.

Calder, J.H. 1998. The Carboniferous evolution of Nova Scotia. In D.J. Blundell and A.C. Scott (eds.), Lyell: the Past is the Key to the Present. Geological Society, London, Special Publications, 143, pp. 261-302.

CAlder, J.H. \& Gibling, M.R. 1994. The Euramerican Coal Province: controls on Late Paleozoic peat accumulation. Palaeogeography, Palaeoclimatology, Palaeoecology, 106, pp. $1-21$.

COPELAND, M.J. 1957. The Arthropod fauna of the Upper Carboniferous rocks of the Maritime Provinces. Geological Survey of Canada, Memoir, 286, $110 \mathrm{p}$.

Dawson, J.W. 1868. Acadian Geology. The Geological Structure, Organic Remains, and Mineral Resources of Nova Scotia, New Brunswick and Prince Edward Island. 2nd ed., Macmillan, London, $694 \mathrm{p}$.

DUNLOP, J.A. 1996. A trigonotarbid arachnid from the Upper Silurian of Shropshire. Palaeontology, 39, pp. 605-614.

DuNLOP, J.A. 1999. A new specimen of the trigonotarbid arachnid Aphantomartus areolatus Pocock 1911 from the Stephanian of Montceau-les-Mines, France. Neues Jahrbuch für Geologie und Paläontologie Monatshefte, 1, pp. 29-38.

HACQuebard, P.A. 1972. The Carboniferous of eastern Canada. In Septième Congrès International de Stratigraphie et Géologie du Carbonifère, Krefeld, Germany, 1971, Compte Rendu, 1, pp. 69-90.

HACQUEBARD, P.A. \& BARSS, M.S. 1970. Palaeogeography and facies aspects of the Minto coal seam, New Brunswick, Canada. 6th International Congress on Carboniferous Stratigraphy and Geology, Sheffield 1967, Compte Rendu, 3, pp. 861-872.

HARTT, C.F. 1865. On the Devonian plant locality of the "Fern Ledges," Lancaster, N.B., with a detailed section and notes on the fossils. In L.W. Bailey, Observations on the Geology of southern New Brunswick. Fredericton, pp. 131-140.

Kalkreuth, W., Marchioni, D. \& UtTing, J. 2000. Petrology, palynology, coal facies and depositional environments of an Upper Carboniferous coal seam, Minto Coalfield, New Brunswick, Canada. Canadian Journal of Earth Sciences, 37, pp. 1209-1228.

MATTHEW, G.F. 1889. On some remarkable organisms of the Silurian and Devonian rocks in southern New Brunswick. Transactions of the Royal Society of Canada, 6, pp. 49-62.

MatThew, G.F. 1895a. On the organic remains of the Little River Group, No. III. Transactions of the Royal Society of Canada, 12, pp. 101-111.

MATTHEW, G.F. 1895b. Organic remains of the Little River Group, No. IV. Transactions of the Royal Society of Canada, 1, pp. 273-279.

Matthew, G.F. 1897. Description of an extinct Palaeozoic insect, and a review of the fauna with which it occurs. Bulletin of the Natural History Society of New Brunswick, 15, pp. 49-60.

MilleR, R.F. 1999. Report of Gyracanthus (Chordata: Acanthodii) and other Upper Carboniferous fish from the Minto Formation,
New Brunswick (NTS 21 I/4). In B.M.W. Carroll (ed.), Current Research 1998. New Brunswick Department of Natural Resources and Energy, Minerals and Energy Division, Mineral Resource Report, 99-4, pp. 37-43.

Muller, J.E. 1951. Geology and coal deposits of Minto and Chipman map-areas, New Brunswick. Geological Survey of Canada, Memoir, 260, $40 \mathrm{p}$.

OKULITCH, A.V. 1999. Geological time scale, 1999. Geological Survey of Canada, Open File 3040 (National Earth Science Series, Geological Atlas) - REVISION.

Petrunkevitch, A. 1913. A monograph of the terrestrial Palaeozoic Arachnida of North America. Transactions of the Connecticut Academy of Arts and Sciences, 18, pp. 1-137.

Petrunkevitch, A. 1945. Palaeozoic Arachnida of Illinois. An inquiry into their evolutionary trends. Scientific Papers, State of Illinois, 3, pp. 1-72.

Petrunkevitch, A. 1949. A Study of the Palaeozoic Arachnida. Transactions of the Connecticut Academy of Arts and Sciences, 37, pp. 69-315.

PococK, R.I. 1911. A monograph of the terrestrial Carboniferous Arachnida of Great Britain. The Palaeontographical Society, London, Monograph 64, 84 p.

RÖSSLER, R. 1998. Arachniden-Neufunde im mitteleuropäischen Unterkarbon bis Perm-Beitrag zur Revision der Familie Aphantomartidae Petrunkevitch 1945 (Arachnida, Trigonotarbida). Paläontologische Zeitschrift, 72, pp. 67-88.

Rössler, R. \& BraUCKMANN, C. 2000. Der erste Arachniden-Fund im Paläozoikum der Alpen: Aphantomartus pustulatus (Scudder 1884) aus dem ältesten Ober-Karbon (mittleres bis oberes Namurium A) von Nötsch (Österreich). Jahrbuch der Geologischen Bundesanstalt, 142, pp. 227-234.

SCUDDER, S.H. 1884. A contribution to our knowledge of Paleozoic Arachnida. Proceedings of the American Academy of Arts and Sciences, 20, pp. 15-22.

SCUDDER, S.H. 1893. Insect fauna of the Rhode Island coalfield. U.S. Geological Survey Bulletin, 101, pp. 1-27.

Selden, P.A. \& Romano, M. 1983. First Palaeozoic arachnid from Iberia: Aphantomartus areolatus Pocock (basal Stephanian; prov. León, N.W. Spain), with remarks on aphantomartid taxonomy. Boletín Geológico y Minero, 94, pp. 106-112.

ST. PETER, C. 1997. Bedrock geology of the Chipman/Canaan River map are (NTS $21 \mathrm{I} / 04$ and part of $21 \mathrm{H} / 13$, Sunbury, Queens and Kings counties, New Brunswick. New Brunswick Department of Natural Resources and Energy, Minerals and Energy Division, Plate 97-34.

Williams, G.L., FyfFe, L.R., Wardle, R.J., Colman-Sadd, S.P. \& BOEHNER, R.C. 1985. Lexicon of Canadian Stratigraphy, Volume VI, Atlantic Region. Canadian Society of Petroleum Geologists, Calgary, 572 p.

Editorial responsibility: Ron K. Pickerill 